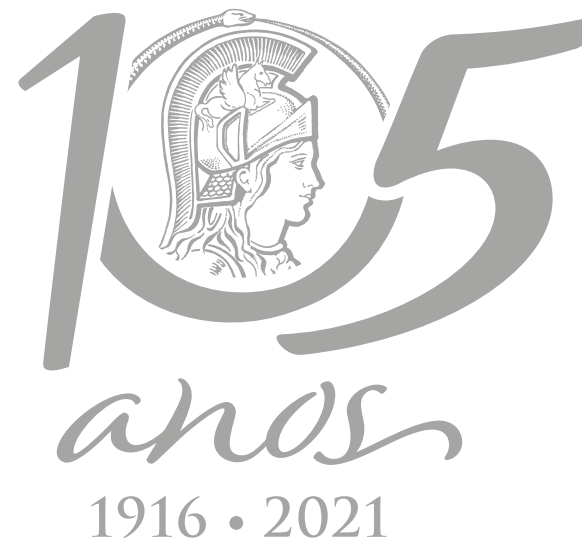

$1916 \cdot 2021$

\title{
ECOSYSTEMS
}

\section{Teissiera polypofera: first record of the genus Teissiera (Hydrozoa: Anthoathecata) in the Atlantic Ocean}

\author{
EVERTON G. TOSETTO, SIGRID NEUMANN-LEITÃO, ARNAUD BERTRAND \& \\ MIODELI NOGUEIRA-JÚNIOR
}

\begin{abstract}
Specimens of Teissiera polypofera Xu, Huang \& Chen, 1991 were found in waters off the northeast Brazilian coast between $8.858^{\circ} \mathrm{S}, 34.809^{\circ} \mathrm{W}$ and $9.005^{\circ} \mathrm{S}, 34.805^{\circ} \mathrm{W}$ and 56 to $717 \mathrm{~m}$ depth. The genus can be distinguished from other anthomedusae by the two opposite tentacles with cnidophores and four exumbrellar cnidocyst pouches with ocelli. Specimens were assigned to Teissiera polypofera due to the long and narrow manubrium transposing bell opening and polyp buds with medusoid buds on it, issuing from the base of manubrium. This study represents the first record of the genus in the Atlantic Ocean.
\end{abstract}

Key words: Jellyfish, cnidaria, taxonomy, biodiversity.

\section{INTRODUCTION}

The presence of stinging pedicellate and contractile cnidocysts buttons on marginal tentacles, named cnidophores, is a distinctive character among Anthoathecata hydromedusae (Bouillon et al. 2006). They occur only on three families of the suborder Capitata, Cladocorynidae Allman, 1872, Teissieridae Bouillon, 1978 and Zancleidae Russell, 1953. These families used to be included in the extinguished superfamily Zancleida (along with Porpitidae Goldfuss, 1818). Another synapomorphy in these three families is the presence of exumbrellar cnidocyst pouches on perradial bulbs (Bouillon 1974, Boero et al. 2000, Bouillon et al. 2006). Cladocorynidae has two opposite marginal tentacles and exumbrellar pouches only on non-tentaculate bulbs. Teissieridae also has two opposite marginal tentacles but with pouches in the four perradial quadrants. Zancleidae may have either four or none pouches and two, four or none marginal tentacles (Bouillon et al. 2004, 2006).

Distinction between Teissieridae and Zancleidae was primarily based on morphology of the clearly distinct hydroid stages. The former with polymorphic colony and incrusting hydrorhiza forming a crust-like stolonal plate and the later with the hydrorhiza formed by creeping stolon tubes covered by perisarc (Petersen 1990, Boero et al. 1996, Bouillon et al. 2006). Medusae from both families have an almost identical body plan and the only recognizable difference is the ocelli that is present only in Teissieridae (Boero et al. 1996, Bouillon et al. 2006). This is not an easy assignment, some Zancleidae species have a dark spot on nematocyst pouches base that may be interpreted as ocellus (Bouillon 1978, Boero et al. 2000). Another problem is the fixation of material in formalin, which may lose these small delicate structures (Bouillon 1978). These factors have led to known misidentifications and genera changes (Bouillon 1978, Bouillon \& 
Boero 2000, Boero et al. 2000, Xu \& Huang 2004, Schuchert 2019).

The genus Teissiera Bouillon, 1974 used to be the unique representative of Teissieridae, presenting characteristics of the family (Bouillon et al. 2006). However, the genus Pseudosolanderia Bouillon \& Gravier-Bonnet, 1988, which produces eumedusoids, were recently included in the taxon (Schuchert 2019). Teissiera was previously described as Teissiera milleporoides Bouillon, 1974 from the Indian Ocean (Bouillon 1974). Three additional species were described from the Pacific (Schuchert 2019), where the genus was exclusively found since then (Bouillon 1978, Xu \& Huang 2004, Kubota 2006, Kubota \& Gravili 2007, Du et al. 2012). In the present paper, we describe specimens assigned to Teissiera, which were recently found at an oceanographic expedition (Bertrand 2015) achieved off Northeast Brazil, representing the first reported occurrence of the genus in Atlantic Ocean waters, and discuss its taxonomy and global distribution.

\section{MATERIALS AND METHODS}

Specimens were obtained during the "Acoustics along the Brazilian coast" survey (ABRACOS 1), carried out on October 20015, on board the French R/V ANTEA off Northeast Brazil (Table I). Samples were collected in oblique hauls, using a bongo plankton net with $300 \mu \mathrm{m}$ mesh and 0.6 $m$ opening, from near bottom to surface over the continental shelf, and $200 \mathrm{~m}$ depth to surface in open waters. Surface temperature and salinity was observed using a Seabird 911 CTD profiler. Material was fixed with $4 \%$ formaldehyde buffered with sodium tetraborate (0.5 g.l-1). Specimens were deposited in the Museu de Invertebrados Paulo Young from Universidade Federal da Paraíba (CIPY1123). All procedures performed in this research were in accordance
Table I. Teissiera polypofera occurrences off northeast Brazil.

\begin{tabular}{|c|c|c|c|c|}
\hline $\begin{array}{c}\text { Number of } \\
\text { specimens }\end{array}$ & Location & $\begin{array}{c}\text { SST } \\
\left.\mathbf{(}^{\circ} \mathbf{C}\right)\end{array}$ & SSS & $\begin{array}{c}\text { Bottom } \\
\text { depth (m) }\end{array}$ \\
\hline 4 & $\begin{array}{r}8.858^{\circ} \mathrm{S}, \\
34.809^{\circ} \mathrm{W}\end{array}$ & 26.65 & 36.62 & 56 \\
\hline 1 & $\begin{array}{r}9.005^{\circ} \mathrm{S}, \\
34.805^{\circ} \mathrm{W}\end{array}$ & 26.76 & 36.79 & 717 \\
\hline
\end{tabular}

SST = sea surface temperature; SSS = sea surface salinity.

with the ethical standards of the Universidade Federal de Pernambuco. All necessary permits for sampling and observational field studies have been obtained by the authors from the competent authority (SISBIO 47270-4).

\section{RESULTS AND DISCUSSION}

Specimens presented a bell-shaped umbrella almost spherical, with the mesoglea thicker in the apical region (Figure 1a, b). Umbrella height ranged from 0.7 to $1.2 \mathrm{~mm}$ and width from 0.5 to $1 \mathrm{~mm}$. All five specimens analyzed presented umbrella margin with two perradial opposite marginal bulbs bearing tentacles with cnidophores. All preserved specimens had four oval perradial exumbrellar cnidocyst pouches connected to the ring canal by a slender peduncle (Figure 1a, c). A small reddish-brown ocellus was observed in the central portion of some cnidocyst pouches (arrow in Figure 1c). Manubrium narrow and long, exceeding bell opening in larger specimens (Figure 1b). Four out of five specimens presented many capitate polyp buds issuing from the upper portion of manubrium (Figure 1d, e). Several medusoid buds were also observed issuing from these hydrants (Figure 1d, e).

The combination of two opposite tentacles with cnidophores and four exumbrellar cnidocyst pouches each with an ocellus assigned the 

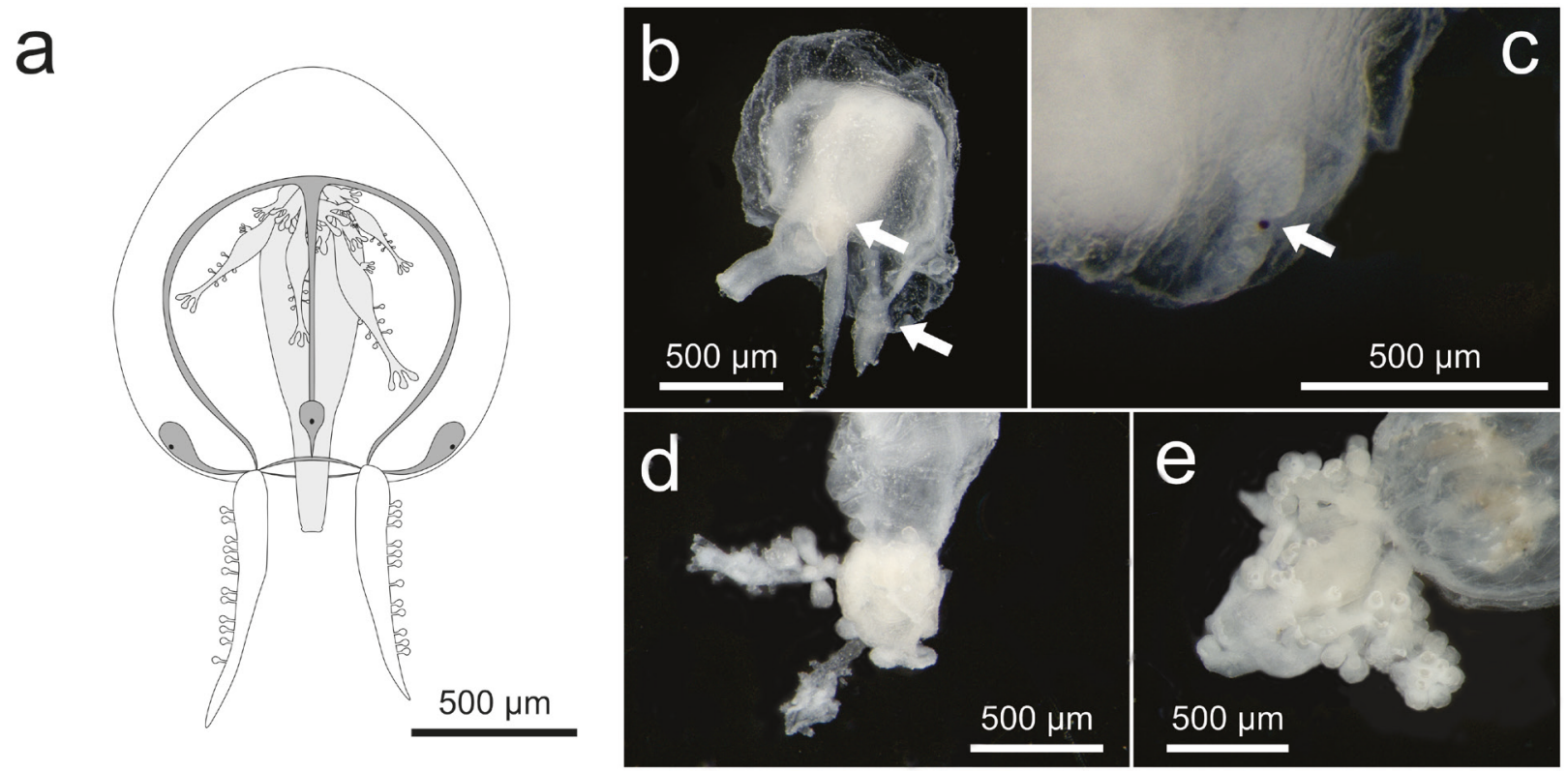

Figure 1. Teissiera polypofera from Western Atlantic Ocean. (a) Schematic representation of full specimen. b) full view (arrows indicating tentacle bulbs). (c) detail on exumbrellar cnidocyst pouch with red-brown ocelli (indicated by the arrow). ( $d$ and e) detail on manubrium and several polyp buds and medusoid buds in it.

specimens to the genus Teissiera (Bouillon 1974, Bouillon et al. 2006). Even though ocelli were not present in some specimens, which would assign them to Zanclea Gegenbaur, 1856, these structures may disappear easily due to formalin fixation through time (Bouillon 1978), and we assumed that was the case herein since most specimens had ocelli only in some pouches and those with no ocelli were found in the same sample.

Teissiera medusae species are mainly distinguished based on the position and shape of gonads, length of manubrium and presence of polypoid or medusoid buds issuing from the manubrium (Table II, Bouillon 1978, Xu \& Huang 2004). Although cnidocysts scattered or in ridges on the exumbrella have also been used to distinguish species (e.g. Xu \& Huang 2004), these structures are common on newly released Capitata medusae (Bouillon et al. 2006) and were disregarded herein. Currently, four species were described in Teissiera (Schuchert 2019). Teissiera milleporoides Bouillon, 1974 and Teissiera australe Bouillon, 1978 do not produce buds and have a short manubrium never reaching the bell margin (Table II, Bouillon 1974, 1978). Thus, they clearly do not match with the present specimens. Polypoid buds have been observed in the two remaining species, Teissiera medusifera Bouillon, 1978 and Teissiera polypofera Xu, Huang \& Chen, 1991, both distinguished mainly based on the relative manubrium length; the former with a shorter manubrium never exceeding bell opening and the latter the opposite (Table II, Bouillon 1978, Xu \& Huang 2004). Therefore, despite small differences such as the presence of cnidocysts in the exumbrella, our specimens match to $T$. polypofera diagnosis.

Geographic distribution of Teissiera species were until now restricted to the Indian and Western Pacific Ocean, mainly in tropical and subtropical areas (Figure 2). The genus was first described from hydroids and its released medusae of $T$. milleporoides found in the Seychelles islands, Western Indian Ocean 
Table II. Comparison of main characters of the valid medusae species of the genus Teissiera.

\begin{tabular}{|c|c|c|c|c|c|c|c|}
\hline Species & $\begin{array}{c}\text { Height } \\
(\mathrm{mm})\end{array}$ & $\begin{array}{l}\text { Width } \\
(\mathrm{mm})\end{array}$ & Umbrella & Manubrium & Gonads & Ocellus & Reference \\
\hline $\begin{array}{c}\text { Present } \\
\text { specimens of } \\
\text { Teissiera } \\
\text { polypofera }\end{array}$ & 1.2 & 1 & $\begin{array}{c}\text { Bell shaped; } \\
\text { mesoglea thicker } \\
\text { in the apical } \\
\text { region }\end{array}$ & $\begin{array}{c}\text { Narrow and long; } \\
\text { exceeding bell } \\
\text { opening; with } \\
\text { polyp buds and } \\
\text { medusa buds } \\
\text { on it }\end{array}$ & $\begin{array}{c}\text { Not } \\
\text { observed }\end{array}$ & $\begin{array}{l}\text { Red- } \\
\text { brown }\end{array}$ & This study \\
\hline $\begin{array}{l}\text { Teissiera } \\
\text { australe }\end{array}$ & 3.5 & 3 & $\begin{array}{c}\text { Mesoglea thicker } \\
\text { in the apical } \\
\text { region }\end{array}$ & $\begin{array}{c}\text { Up to } 2 / 3 \text { of } \\
\text { subumbrellar } \\
\text { cavity }\end{array}$ & $\begin{array}{l}\text { Interradial; } \\
\text { covering up } \\
\text { to } 2 / 3 \text { of } \\
\text { manubrium }\end{array}$ & $\begin{array}{l}\text { Bright } \\
\text { red }\end{array}$ & $\begin{array}{l}\text { Bouillon } \\
1978\end{array}$ \\
\hline $\begin{array}{l}\text { Teissiera } \\
\text { medusifera }\end{array}$ & 1.3 & 1 & $\begin{array}{l}\text { Thick conical } \\
\text { mesoglea in the } \\
\text { apical region }\end{array}$ & $\begin{array}{c}\text { Short; with } \\
\text { medusa buds; } \\
\text { one specimen } \\
\text { with a polyp bud }\end{array}$ & $\begin{array}{l}\text { interradial } \\
\text { in the upper } \\
\text { half of } \\
\text { manubrium, } \\
\text { eggs in } \\
\text { the apical } \\
\text { mesoglea }\end{array}$ & $\begin{array}{l}\text { Red- } \\
\text { brown }\end{array}$ & $\begin{array}{l}\text { Bouillon } \\
1978\end{array}$ \\
\hline $\begin{array}{c}\text { Teissiera } \\
\text { milleporoides }\end{array}$ & 0.5 & 0.6 & $\begin{array}{l}\text { Mesoglea thicker } \\
\text { near cnidocyst } \\
\text { pouches; } \\
\text { exumbrella with } \\
\text { cnidocysts }\end{array}$ & $\begin{array}{c}\text { Half of } \\
\text { subumbrellar } \\
\text { cavity }\end{array}$ & $\begin{array}{c}\text { Not } \\
\text { observed }\end{array}$ & $\begin{array}{l}\text { Red- } \\
\text { brown } \\
\text { with a } \\
\text { yellow } \\
\text { central } \\
\text { spot }\end{array}$ & $\begin{array}{l}\text { Bouillon } \\
1974\end{array}$ \\
\hline $\begin{array}{c}\text { Teissiera } \\
\text { polypofera }\end{array}$ & 1.3 & 0.5 & $\begin{array}{c}\text { Spherical; } \\
\text { exumbrella many } \\
\text { cnidocysts }\end{array}$ & $\begin{array}{c}\text { Narrow and long; } \\
\text { exceeding bell } \\
\text { opening; with } \\
\text { polyp buds and } \\
\text { medusa buds } \\
\text { on it }\end{array}$ & $\begin{array}{c}\text { Not } \\
\text { observed }\end{array}$ & Present & $\begin{array}{l}\text { Xu \& } \\
\text { Huang } \\
2004\end{array}$ \\
\hline
\end{tabular}

(Bouillon 1974), later it was reported in Japanese waters (Kubota \& Gravili 2007). T. australe and T. medusifera were fist described off Papua New Guinea, and later found off China (Bouillon 1978, Xu et al. 1991, Du et al. 2012). T. polypofera were described and found only off China as well (Xu et al. 1991, Xu \& Huang 2004, Li et al. 2006). Moreover, two unidentified species of the genus were found in the Japanese Nansei Islands (Kubota 2006).
In this study T. polypofera, was observed in tropical Brazilian waters in the Western Atlantic Ocean with surface temperature and salinity around $26.7^{\circ} \mathrm{C}$ and 36.7 respectively (Table I). This disjunct distribution of T. polypofera is worthy of attention (Figure 2). Given the fragility of the ocelli used to distinguish Teissiera species from Zanclea (see above), many previous occurrences of Teissiera may have been erroneously classified as the later due to absence of ocelli. 


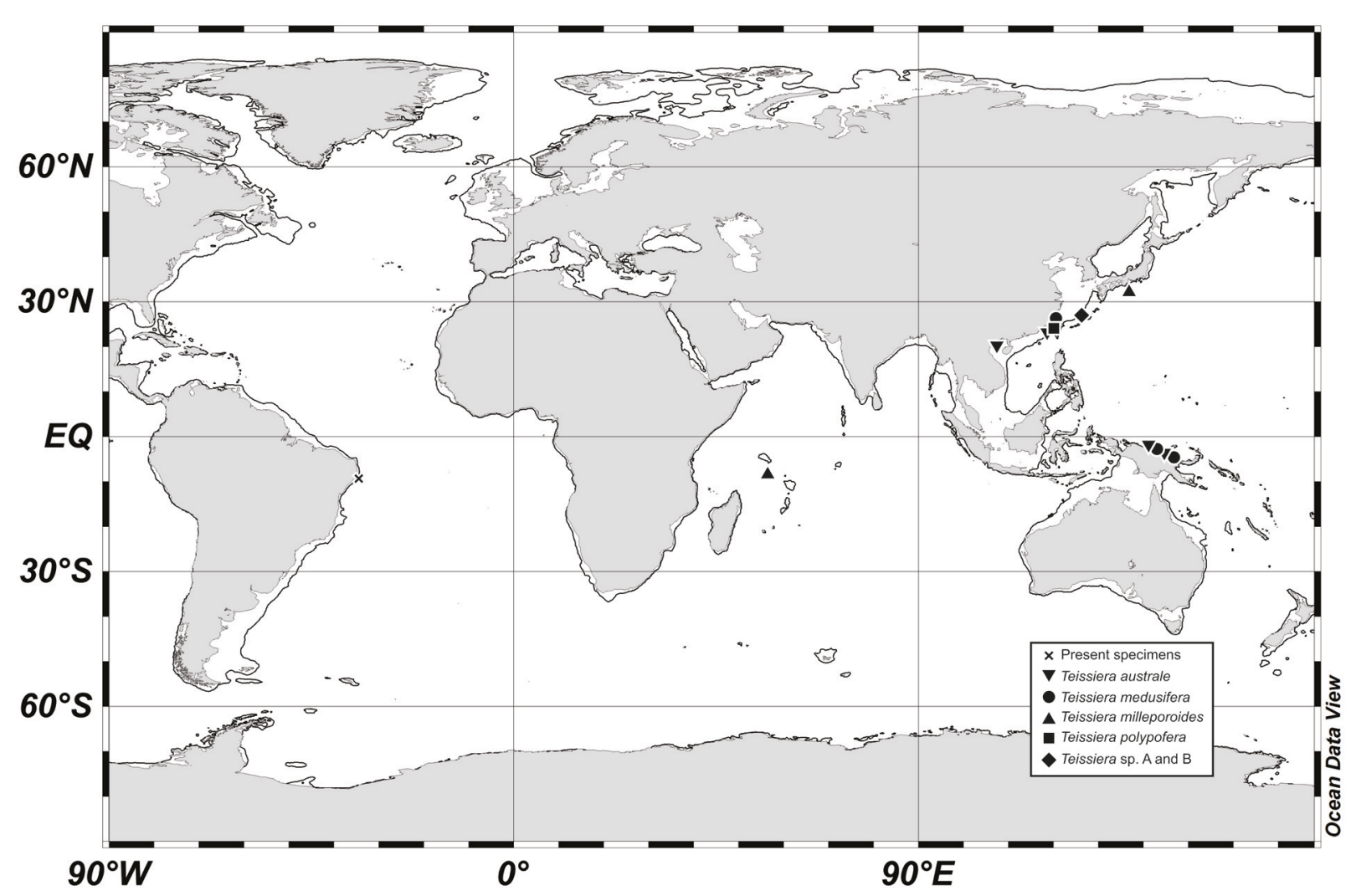

Figure 2. Global distribution of Teissiera species based on this study and literature records (Bouillon 1974, 1978, Xu et al. 1991, Xu \& Huang 2004, Kubota 2006, Li et al. 2006, Kubota \& Gravili 2007, Du et al. 2012). The dashed line shows the $250 \mathrm{~m}$ isobath, roughly corresponding to the shelf break. Generated using Ocean Data View software (Schlitzer 2019).

This is particularly true when considering Zanclea medusopolypata Boero, Bouillon \& Gravili, 2000, which is morphologically similar to T. polypofera and both species have even been erroneously argued to be the same (Boero et al. 2000, Xu \& Huang 2004). Thus, previous occurrences of Zanclea costata and Zanclea sp. medusae off the Brazilian coast could have been misidentifications of Teissiera species (Navas Pereira, 1984, Gusmão et al. 2014). Furthermore, cnidarian biodiversity of South Atlantic Ocean is still poorly known when compared to other oceanic basins, mainly considering North and Northeast Brazil (Oliveira et al. 2016, Tosetto et al. 2018). The lack of knowledge associated with taxonomic problems may be covering up a widespread distribution of Teissiera species.

A less plausible hypothesis could be T. polypofera being an invasive species in Brazilian waters transported by ballast water in transoceanic ships. In fact, in the last few decades, a large harbor was installed at Pernambuco state in Brazil (Silva et al. 2004). However, it is about $65 \mathrm{~km}$ away from the spot specimens were collected and it would be unlikely the species reach this far. It is important to note that the species or genus was never reported as invasive elsewhere in the world. Anyway, further studies should be aware to the presence of $T$. polypofera in the area and the development of its populations, aiming to 
understand its global biodiversity patterns and invasive potential as well.

\section{Acknowledgments}

We acknowledge the French oceanographic fleet for funding the survey ABRAÇOS 1 and the officers, crew and scientific team of the R/V Antea for their contribution to the success of the operations. The present study could not have been done without the support of all participants from the LABZOO and the laboratories at Universidade Federal de Pernambuco and Universidade Federal Rural de Pernambuco. We thank the Conselho Nacional de Desenvolvimento Científico e Tecnológico (CNPq), which provided student scholarship to EGT (grant 140897/2017-8). This work is a contribution to the LMI TAPIOCA (www.tapioca.ird.fr).

\section{REFERENCES}

BERTRAND A. 2015. ABRACOS cruise, RV Antea. https://doi. org $/ 10.17600 / 15005600$

BOERO F, BOUILLON J \& GRAVILI C. 2000. A survey of Zanclea, Halocoryne and Zanclella (Cnidaria, Hydrozoa, Anthomedusae, Zancleidae) with description of new species. Ital J Zool 67: 93-124.

BOERO F, BOUILLON I \& PIRAINO S. 1996. Classification and phylogeny in the Hydroidomedusae (Hydrozoa, Cnidaria). Sci Mar 60: 17-33.

BOUILLON J. 1974. Description de Teissiera milleporoides, nouveau genre et nouvelle espèce de Zancleidae des Seychelles (Hydrozoaires; Athécates-Anthoméduses), avec une révision des hydroïdes «Pteronematoidea». Cah Biol Mar 15: 113-154.

BOUILLON J. 1978. Hydroméduses de la Mer de Bismarck (Papouasie Nouvelle-Guinée). Partie I: Anthomedusae Capitata (Hydrozoa - Cnidaria). Cah Biol Mar 19: 249-297.

BOUILLON I \& BOERO F. 2000. Synopsis of the families and genera of the hydromedusae of the world, with a list of the worldwide species. Thalasia Salent 24: 47-296.

BOUILLON J, GRAVILI C, PAGÈS F, GILI JM \& BOERO F. 2006. An introduction to Hydrozoa. Paris: Pub Sci Mus, 591 p.

BOUILLON J, MEDEL MD, PAGĖS F, GILI JM, BOERO F \& GRAVILI C. 2004. Fauna of the Mediterranean Hydrozoa. Sci Mar 68: 5-438.
DU F, XU Z, HUANG I \& GUO D. 2012. Studies on the medusae (Cnidaria) from the Beibu gulf in the northern south China Sea, with description of three new species. Acta Zootaxonomica Sin 37: 506-519.

GUSMÃO LMO, DIAZXFG, MELO JRM, SCHWAMBORN R \& NEUMANNLEITÃO S. 2014. Jellyfish diversity and distribution patterns in the tropical Southwestern Atlantic. Mar Eco 1-11

KUBOTA S. 2006. Hydromedusan fauna of the Nansei Islands. Proceedings of the 10th International Coral Reef Symposium, 197-201.

KUBOTA S \& GRAVILI C. 2007. List of Hydromedusae (excluding Siphonophora, Milleporidae and Actinulidae) in Japan. Nankiseibutu 49: 189-204.

LI S, HUANG J, GUO D, XU Z \& CHEN G. 2006. Study on ecology of marine plankton in Taiwan strait, China. J Xiamen Univ 45: 24-31.

NAVAS PEREIRA D. 1984. New record of budding in Zanclea costata (Anthomedusae, Zancleidae). Dusenia 14:89-93

OLIVEIRA OMP ET AL. 2016. Census of Cnidaria (Medusozoa) and Ctenophora from South American marine waters. Zootaxa 4194: 1-256.

PETERSEN KW. 1990. Evolution and taxonomy in capitate hydroids and medusae (Cnidaria: Hydrozoa). Zool J Linnean Soc 100: 101-231.

SCHLITZER R. 2019. Ocean data view. https://odv.awi.de.

SCHUCHERT P. 2019. World Hydrozoa Database. http:// www.marinespecies.org.

SILVA AP, NEUMANN-LEITÃO S, SCHWAMBORN R, GUSMÃO LMO \& SILVA TA. 2004. Mesozooplankton of an impacted bay in North Eastern Brazil. Braz Arch Biol Technol 47: 485-493.

TOSETTO EG, NEUMANN-LEITÃO S \& NOGUEIRA JÚNIOR M. 2018. New records of Pegantha spp. (Hydrozoa: Narcomedusae) off Northern Brazil. Pap Avulsos Zool 58: e20185849.

XU Z \& HUANG J. 2004. A survey on Anthomedusae (Hydrozoa: Hydroidomedusae) from Taiwan Strait with description of new species and new combinations. Acta Oceanologica Sin 23: 549-562.

XU Z, HUANG I \& CHE X. 1991. On new species and record of Hydromedusae in the upwelling region off the MinnanTaiwan Bank Fishing ground, China. Minnan-Taiwan Bank Fishing Ground Upwelling Ecosystem Study, p. 469-486. 


\section{How to cite}

TOSETTO EG, NEUMANN-LEITÃO S, BERTRAND A \& NOGUEIRA-JÚNIOR M. Teissiera polypofera: first record of the genus Teissiera (Hydrozoa: Anthoathecata) in the Atlantic Ocean. An Acad Bras Cienc 93: e20191437. DOI 10.1590/0001-3765202120191437.

Manuscript received on November 21, 2019;

accepted for publication on February 07, 2020

EVERTON G. TOSETTO 1

https://orcid.org/0000-0002-4020-0942

\section{SIGRID NEUMANN-LEITÃO}

https://orcid.org/0000-0001-7878-8772

\section{ARNAUD BERTRAND ${ }^{1,2,3}$}

https://orcid.org/0000-0003-4723-179X

\section{MIODELI NOGUEIRA-JÚNIOR}

https://orcid.org/0000-0001-5409-8312

1 Universidade Federal de Pernambuco,

Departamento de Oceanografia, Avenida

Arquitetura, S/ N, 50670-901 Recife, PE, Brazil

${ }^{2}$ Institut de Recherche pour le Développement (IRD),

MARBEC, Univ Montpellier, CNRS, Ifremer, IRD, Sète, France.

${ }^{3}$ Universidade Federal Rural de Pernambuco,

Departamento de Pesca e Aquicultura, Rua D. Manuel

de Medeiros, S/N, 52171-900 Recife, PE, Brazil

${ }^{4}$ Universidade Federal da Paraíba, Departamento

de Sistemática e Ecologia, Via Pau Brasil, S/N,

58051-900 João Pessoa, PB, Brazil

Corresponding author: Everton G. Tosetto

E-mail:evertontosetto@hotail.com

\section{Author contributions}

Experiment design: S.N.L. and A.B. Sampling: A.B. Sorting of Material: E.G.T. Species identification: E.G.T. and M.N.J. Manuscript writing: E.G.T., M.N.J., S.N.L. and A.B. Manuscript review: E.G.T., M.N.J., S.N.L. and A.B.

\section{(cc) BY}

